\title{
Mandible characteristics and allometric relations in copepods: a reliable method to estimate prey size and composition from mandible occurrence in predator guts
}

\author{
Caracterización de mandíbulas y relación alométrica en copépodos: \\ método adecuado para estimar tamaño y composición de presas usando mandíbulas \\ encontradas en intestinos de depredadores
}

RICARDO GIESECKE \& HUMBERTO E. GONZÁLEZ

Institute of Marine Biology "Jürgen Winter", Universidad Austral de Chile, P.O. Box 567, Valdivia, Chile and Centre for Oceanographic Research in the Eastern South-Pacific (COPAS) Corresponding author: e-mail: ricardogiesecke@uach.cl

\begin{abstract}
The size and shape of the cutting edge of the mandibles from the five most abundant copepod species found in Mejillones Bay are described with the aim to create a helpful tool for the identification of copepod prey and their size from predator gut contents. Good allometric relationships were found between the carapace length and the mandible width for the species Paracalanus parvus, Centropages brachiatus and Acartia tonsa. By contrast, the cyclopoids Oithona sp. and Corycaeus sp. did not present a good relationship between these two parameters, presumably due to the presence of more than a species in the study area. Applying the edge index (Itoh 1970) the copepods were classified as herbivores (e.g., P. parvus), omnivores (e.g., C. brachiatus and A. tonsa), and carnivores (e.g., Oithona sp.). In general, there was a tight relationship between the morphometric characters of the mandible blade and the trophic ecology of each species. The good relationship between the mandible width and the carapace length of the calanoid species will permit the estimation of the size of an ingested copepod by a predator, within a certain degree of accuracy, by measuring the width of the mandibles found in gut contents. This relationship and the supplementary characterization of the mandible blade will help improve the knowledge of the feeding ecology of the mesozooplankton in northern Chile.
\end{abstract}

Key words: copepod mandibles, feeding habits in copepods, gut content analysis, Humboldt Current System.

\section{RESUMEN}

El tamaño y forma del extremo cortante de la mandíbula de las cinco especies de copépodos más abundantes en la bahía de Mejillones fueron descritas con el propósito de crear una herramienta útil para la identificación de contenidos intestinales de depredadores de copépodos. Aparte de esto, se analizó la relación alométrica entre la longitud cefalotoráxica y el diámetro mandibular para las especies Paracalanus parvus, Centropages brachiatus Acartia tonsa, Oithona sp. y Corycaeus sp. A diferencia de las especies calanoídeas, las especies ciclopoídeas no presentaron una buena correlación entre estos dos parámetros, presumiblemente debido a la presencia de más de una especie en la zona de estudio. Aplicando el "índice de borde" (Itoh 1970) se clasificaron los copépodos según sus hábitos alimenticios en: herbívoros ( $P$. pavus), omnívoros $(C)$ brachiatus y $A$. tonsa) y carnívoros (Oithona sp.). En general se advirtió una cercana relación entre los caracteres morfométricos de la mandíbula y la ecología trófica de cada especie. Las buenas relaciones entre el diámetro mandibular y la longitud cefalotoráxica de las especies de copépodos calanoídeos permitirán a futuro determinar con cierta exactitud el tamaño de la presa ingerida basándose solamente el ancho de la mandíbula encontradas en contenidos intestinales. Aplicando esta correlación en conjunto con las caracterizaciones mandibulares individuales, permitirán precisar con mayor exactitud estimaciones de la ecología alimenticia del mesozooplancton del norte de Chile.

Palabras clave: mandíbulas de copépodos, hábitos alimenticios en copépodos, análisis contenido intestinal, Sistema de Corriente de Humboldt. 


\section{INTRODUCTION}

Copepods are one of the most abundant zooplanktonic groups in the world's oceans. Its great biomass, combined with their feeding habits makes them the principal linkage between higher and basal trophic levels. However, quantitative and qualitative information on energy flow to higher trophic levels and the different pathways in the carnivorous link of the trophic food web is still scarce in the HCS off Chile. The main difficulty in obtaining this information is the reliable determination of the identity and size of parts of semi digested prey within predator guts. Many predators tear apart their prey during digestion and therefore body shape and size of the prey cannot be used for their identification. Therefore, a method based on the identification of mandible cutting edges has been proposed. These structures present the following properties: (1) they have a species-specific shape (Itoh 1970), (2) they pass undamaged through the guts of predators (Øresland 1991, Båmstedt et al. 2000, Giesecke \& González 2004) and, (3) their size is related to the animal body size (Karlson \& Båmstedt 1994, Saito \& Kiørboe 2001).

Since mandibles have species-specific shapes related principally to feeding mode, they have also been used to classify copepods by their feeding modes: carnivorous or raptorial feeders, herbivorous or filter feeders and omnivorous (Itoh 1970, Sullivan et al. 1975, Ohtsuka \& Onbé 1989, 1991, Ohtsuka et al. 1996). The shape, chemical composition, number and position of the teeth are characters that are closely linked to the feeding preference of copepods and have been used to clarify their niches in marine food web (Ohtsuka \& Onbé 1989, 1991).

In this study we describe the shape of the mandible of the five most abundant copepod species in northern Chile and establish relations to their feeding modes. We also evaluate the use of allometric relations between the mandible width (MW) and the carapace length (CL) of three calanoid species as a method to estimate prey length from occurrence of copepod mandibles in predator guts.

\section{MATERIAL AND METHODS}

The zooplankton samples were collected from Mejillones Bay at stations located at $23^{\circ} 00^{\prime} 15^{\prime \prime}$
S, $70^{\circ} 26^{\prime} 43^{\prime \prime} \mathrm{W}$, during the February 7 and 8 , 2001 at $\sim 15 \mathrm{~km}$ from the coast on the continental shelf with a bottom depth about $130 \mathrm{~m}$ Zooplankton samples were taken using a WP-2 net with a $200 \mathrm{~mm}$ mesh size (UNESCO 1968), that was towed vertically along a depth strata between $0-100 \mathrm{~m}$ and subsequently preserved in $5 \%$ formaldehyde-sea water. A TSK flowmeter was mounted between the middle and the ring of the net opening to quantify the volume of water filtered by the net.

In the laboratory, zooplankton samples were splitted and copepods were identified to species level. The fraction of each sample analyzed ranged from $1 / 32$ to $1 / 128$ of the total sample, depending on the abundance of zooplankton in each sample. In all cases sub-samples included at least 200 zooplankton items. For less concentrated samples the entire sample was analyzed.

Carapace length (CL) of the five most common species were measured under a stereomicroscope (Leica MZ6), at $40 \times$ magnification with a precision of $10 \mu \mathrm{m}$. Mandible blades of calanoid species (Paracalanus parvus, Centropages brachiatus and Acartia tonsa) and cyclopoid copepods (Oithona sp. and Corycaeus sp.) were dissected using tungsten needles of 0.1 and $0.2 \mathrm{~mm}$ in diameter using polyvinyllactophenol as the dissecting fluid, and measured under a Microscope (Nikon TS 100) at $400 \mathrm{x}$ magnification. Males of $P$. parvus were not included in this study because their mandible blades are normally reduced (Schnack 1982, Saito \& Kiørboe 2001), and copepod species were not classified into developmental stages due to the limited knowledge we have on this matter for almost all species.

The mandible edge index proposed by Itoh (Itoh 1970) was applied to characterize the feeding modes of the copepod species:

$$
\text { Edge Index }=\sum\left(\frac{\frac{w_{i}}{W} \times \frac{h_{i}}{H} \times 10^{4}}{N}\right)
$$

where $\mathrm{w}_{\mathrm{i}}$ is the space between each pair of teeth, $\mathrm{W}$ is the total width of the mandible blade, $\mathrm{h}_{\mathrm{i}}$ is the height of each tooth, $\mathrm{H}$ is the total height of the cutting edge and $\mathrm{N}$ is the total number of teeth on the mandible blade (Fig. 1). Each variable was measured from digital photographs, using the software Scion Image 4.0.2. An edge 


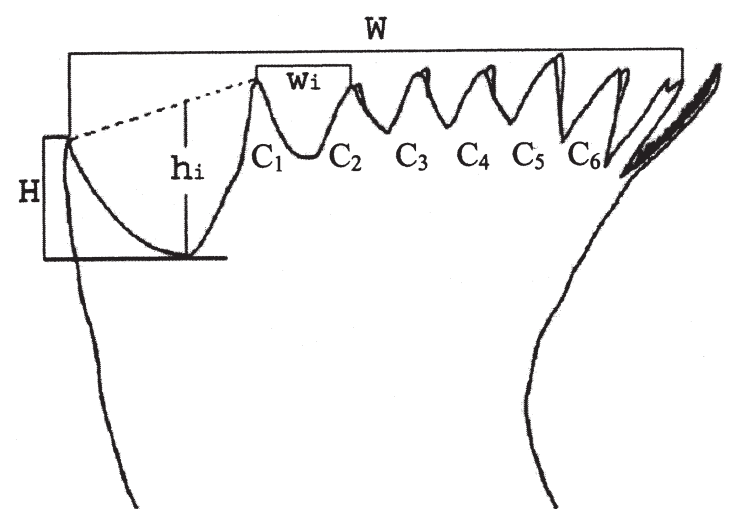

Fig. 1: Variables used to estimate the Itoh "edge index".

Variables utilizadas para estimar el índice de Itoh.

index below 500 indicates that the species has a predominantly herbivorous feeding mode or Type I. Species with an edge index between 500 and 900 are considered as omnivores (Type II) while those whose index is greater than 900 are carnivores (Type III) (Itoh 1970). Teeth were denominated as $\mathrm{V}_{1}$ for the ventralmost tooth (Fig. 2) and as $C_{n}$ for the rest, where $n$ is the number of teeth preceding $\mathrm{V}_{1}$.

To determine the components of variation in MW related to the CL between the three calanoid copepod species, an ANCOVA analysis was preformed using log-log transformed data. The parallelism assumption of ANCOVA (i.e., interaction with the covariate) was checked using an ANCOVA homogeneity-of slopes model. The relative size of the MW as a percentage of the CL of the three calanoid copepod species were related with the value obtained by the Itoh edge index. Thus, an ANOVA analysis was applied to assess the relationship between the different feeding modes and the $\mathrm{M}$.

\section{RESULTS}

The most common copepods were the calanoids Paracalanus parvus (41.6\%), Acartia tonsa (22.8\%), Centropages brachiatus $(2.7 \%)$ and the cyclopoids Oithona sp. (6.2\%) and Corycaeus sp. (3\%). Schematic drawings of the mandible cutting edges for each of these species are shown in (Fig. 2). In general, the ventralmost tooth $\left(\mathrm{V}_{1}\right)$ (see Fig. 2B) is the largest tooth on mandible and varies in shape among species. $P$. parvus has an elongated, blunt-shaped $\mathrm{V}_{1}$ tooth (Fig. 2B), in contrast to Oithona sp. (Fig. 2E), whose $\mathrm{V}_{1}$ tooth is sharper than that of $P$. parvus and also those of A. tonsa (Fig. 2A) and C. brachiatus (Fig. 2C). The second tooth is monocuspid in A. tonsa and Corycaeus sp. (Fig. 2D) and bicuspid in P. parvus, C. brachiatus and Oithona sp. In general, the size and shape of the teeth varied from a very molar shape in $P$. parvus with eight small bicuspid $\left(\mathrm{C}_{1}-\mathrm{C}_{8}\right)$ and one monocuspid teeth $\left(\mathrm{C}_{9}\right)$, to seven sharp monocuspid teeth in Oithona sp. The mandible shape of $A$. tonsa is somewhat similar to that of $C$. brachiatus, differing principally in the number of teeth; while A. tonsa has five monocuspid teeth and a thin mandible, $C$. brachiatus has one monocuspid $\left(\mathrm{C}_{1}\right)$ and six $\left(\mathrm{C}_{2}-\mathrm{C}_{7}\right)$ bicuspid teeth and a thicker mandible blade.

Three different groups are clearly recognizable from Itoh's edge index, which represent the different feeding modes (Table 1). The low edge indices $(<500)$ of $P$. parvus and Corycaeus sp. suggest that these species are predominantly herbivorous. Values between 896 and 703 for $A$. tonsa and $C$. brachiatus, respectively, suggest that these species are omnivorous. Oithona sp. would be the only carnivorous copepod species since its edge index exceeds 1,000 .

Figure 3 shows that at any CL of the calanoid copepods $P$. parvus, $C$. brachiatus and $A$. tonsa, their MW differ substantially (ANCOVA, $\mathrm{P}<0.001)$, being larger in $P$. parvus $(\mathrm{Ta}-$ ble 3$)$. However, the similar slopes of these relationships (ANCOVA, $\mathrm{P}=0.28$ ) indicate a similar increase of the MW relative to body size (CL).

For the cyclopoid species, no significant relationships between MW and CL were observed, therefore these species were only used to characterize their mandible cutting edges.

\section{DISCUSSION}

One of the main problems in the identification of mandible blades using light microscopy is the limitations involved in recognizing threedimensional shapes of structures. Scanning electron microscopy, in contrast, would be a preferable technique especially in the identification of more complex mandibular shapes such as the mandibles of Calanus plumchrus and Pseudocalanus sp. (Sulivan et al. 1975). 
A

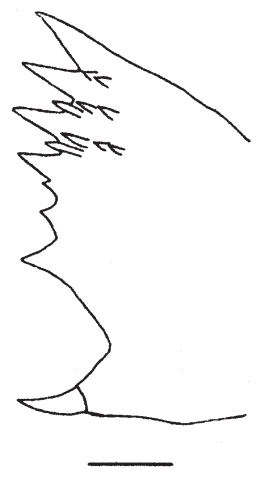

$\mathrm{D}$

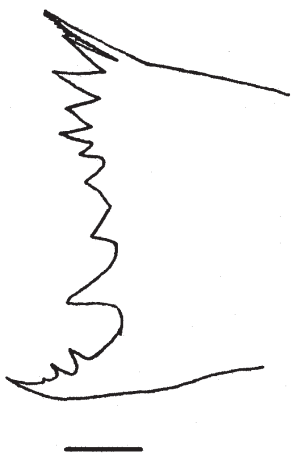

B

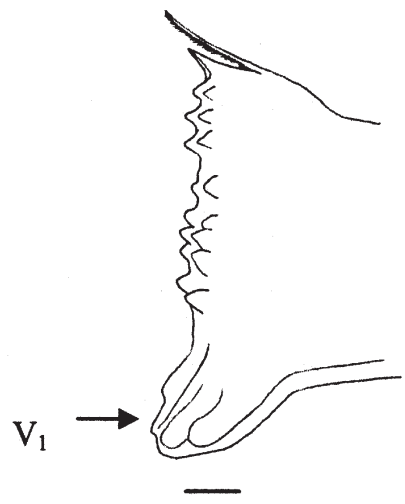

$\mathrm{E}$
$\mathrm{C}$

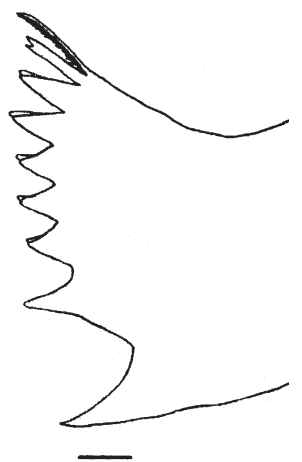

Fig. 2: Schematic drawings of the mandible blades of five copepod species examined in this study. (A) Left mandible blade of Acartia tonsa of $825 \mu \mathrm{m}$; (B) right mandible blade of Paracalanus parvus of $825 \mu \mathrm{m}$; (C) left mandible blade of Centropages brachiatus of $875 \mu \mathrm{m}$; (D) left mandible blade of Corycaeus sp. of $650 \mu \mathrm{m}$; (E) left mandible blade of Oithona sp. of $475 \mu \mathrm{m}$. All measurements of copepods were made based on the carapace length. $\mathrm{V}_{1}$ denote the location of the ventralmost tooth. Scale bars $=10 \mu \mathrm{m}$.

Dibujos esquemáticos del extremo cortante de la mandíbula de las cinco especies de copépodos examinadas en este estudio. (A) Mandíbula izquierda de Acartia tonsa de $825 \mu \mathrm{m}$; (B) mandíbula derecha de Paracalanus parvus de $825 \mu \mathrm{m}$; (C) mandíbula izquierda de Centropages brachiatus de $875 \mu \mathrm{m}$; (D) mandíbula izquierda de Corycaeus sp. de $650 \mu \mathrm{m}$; (E) mandíbula izquierda de Oithona sp. de $475 \mu \mathrm{m}$. Todas las mediciones se realizaron en base a la longitud cefalotoráxica de los copépodos. $\mathrm{V}_{1}$ indica la ubicación del diente ventral. La barra de escala representa $10 \mu \mathrm{m}$.

TABLE 1

Mean (standard deviation in parenthesis) edge index of the five most abundant copepod species of Mejillones Bay

Promedio (desviación estándar en paréntesis) del índice de borde de las cinco especies más abundantes de copépodos en la bahía de Mejillones

\begin{tabular}{lcc}
\hline Species & Edge Index $( \pm$ SD) & Number of replicates \\
\hline Paracalanus parvus & $254(29)$ & 15 \\
Corycaeus sp. & $467(18)$ & 7 \\
Centropages brachiatus & $703(23)$ & 11 \\
Acartia tonsa & $896(43)$ & 14 \\
Oithona sp. & $1771(21)$ & 8 \\
\hline
\end{tabular}


However, the first technique is more practical when a large number of samples must be analyzed and will therefore be more useful with gut content analysis. In this study, the five types of mandibles differed substantially, therefore minimizing the limitations in the use of light microscopy for the identification of copepod species based on their mandible blades. Based strictly on the Itoh index, the species were classified into one of the three different feeding modes: the herbivorous species were $P$. parvus and Corycaeus sp. the omnivorous were A.ton$s a$ and $C$. brachiatus and the carnivorous species was Oithona sp. (Table 1).

For P. parvus and Corycaeus sp., the morphology of the cutting edges is structurally quite different. While $P$. parvus has a relatively smooth and thick mandibular shape (Fig. 2B), Corycaeus has a sharp-toothed mandibular cutting edge with a large ventral serrated tooth (Fig. 2D). The presence of a serrated tooth has also been observed by Sullivan et al. (1975) on species belonging to the filter feeding group (Eucalanus bungii, Pseudocalanus sp. and Calanus plumchrus). Since the Itoh index of this species is close to 500, this species should be considered as 'herbivorous' with certain tendency to omnivorous. Moreover, previous works on the diet of Corycaeus species have demonstrated that they do feed on copepodites and nauplii of several species (Turner et al. 1984, Landry et al. 1985). In fact, this contradiction might be a flaw in the method proposed by Itoh, and we strongly suggest that the use of this index should be complemented with fee- ding observations from the literature and in situ studies of feeding habits.

Paracalanus parvus has a typical herbivorous mandible shape, characterized by a relatively thick and flat mandible (Fig. 2B). This mandibular structure is used primarily to crush diatom frustules, the principal diet item of the genus Paracalanus (Checkley 1980, Paffenhöfer et al. 1982, Turner 1984). The energetically most efficient method for breaking a diatom is to apply a force over a reduced area of contact between the mandible and the diatom. We suggest that $P$. parvus might have evolved this type of strategy due to the large thick blunt ventralmost tooth, which could be used to fracture the diatoms (Fig. 2B arrow). Once a part of the diatom frustule is cracked, it should be easy to continue breaking it with the help of the nine tiny bicuspid teeth. The shape of $P$. parvus mandibles on this study differs slightly from observations made on the same specie by Schnack (1982) in Kiel Bay. Scknack's representation of the cutting edge reveal a more short sharpened $\mathrm{V}_{1}$ tooth and an apparently absence of two rows of teeth's $\left(\mathrm{C}_{1}-\mathrm{C}_{8}\right)$. Whether these morphological differences are due to different feeding modes or food (type and size) availability between Kiel Bay and Mejillones Bay need to be further studied.

The large size of $P$. parvus mandible relative to the body size (as \% CL), in comparison to the other species, indicates that this species is capable of handling larger sized particles, allowing it to feed upon a large size spectrum of diatoms (Checkley 1980, Turner 1984). This

TABLE 2

Mean $( \pm$ SE) and regression statistics of the row data between mandible width (MW) and carapace length $(C L) ; n=$ number of replicates and $r^{2}=$ coefficient of determination

Promedio ( \pm EE) y estadística de regresión entre MW (diámetro mandibular) y CL (longitud cefalotoráxica); $\mathrm{n}=$ número de replicas y $\mathrm{r}^{2}=$ coeficiente de determinación. Valores presentados son originales (no estandarizados)

\begin{tabular}{|c|c|c|c|c|c|c|}
\hline Species & $\mathrm{CL}(\mu \mathrm{m})$ & $\mathrm{MW}(\mu \mathrm{m})$ & Slope & Intercept & $\mathrm{r}^{2}$ & $\mathrm{n}$ \\
\hline P. parvus & $650 \pm 16$ & $61- \pm 1.4$ & $0.083 \pm 0.006 *$ & $7.09 \pm 3.61 \mathrm{NS}$ & 0.88 & 34 \\
\hline C. brachiatus & $1087 \pm 21$ & $86- \pm 1.6$ & $0.073 \pm 0.005 *$ & $6.97 \pm 5.69 \mathrm{NS}$ & 0.86 & 34 \\
\hline A. tonsa & $901 \pm 27$ & $56- \pm 1.8$ & $0.064 \pm 0.003 *$ & $-1.74 \pm 2.74 \mathrm{NS}$ & 0.94 & 29 \\
\hline Oithona sp. & $437 \pm 19$ & $30 \pm 1.5$ & $0.050 \pm 0.019^{*}$ & $8.05 \pm 8.70 \mathrm{NS}$ & 0.369 & 13 \\
\hline Corycaeus sp. & $560 \pm 30$ & $55 \pm 3.6$ & $0.051 \pm 0.049 \mathrm{NS}$ & $25.91 \pm 27.46 \mathrm{NS}$ & 0.181 & 7 \\
\hline
\end{tabular}

(*): $\mathrm{P}<0.002 ;(\mathrm{NS})$ : not significant 
idea is also supported by results obtained by Vargas \& González (2004) in the same study area, who concluded that this species evidenced higher ingestion and clearance rates feeding on centric diatoms $(20-50 \mu \mathrm{m}$ equivalent spherical diameter, ESD). The high abundance of $P$. parvus in the sampling area (Escribano \& Hidalgo 2000, Giesecke \& González 2004) could therefore be attributed to the dominance of chain forming diatoms $(>23 \mu \mathrm{m})$ in the coastal area of northern Chile (Iriarte \& González 2004). An area characterized by frequent upwelling of cold, nutrient-rich waters (Rodríguez et al. 1991, Marín \& Olivares 1999). The in situ abundance of $P$. parvus in Mejillones Bay, demonstrated that males of this species are scarce all year round (P. Hidalgo personal communication), thus, the analysis of allometry, based only on female of this species, should not be significantly based by the exclusion of males.

Based on the Itoh index, the species A.ton$s a$ and $C$. brachiatus belong to "Type II", a group that utilizes both suspension and raptorial feeding modes to capture particles and zooplankton. This feeding group seems to be more complex than the others since they can switch from herbivorous to carnivorous diets depending on the availability of food (Digby 1954, Landry 1981, Kiørboe et al. 1996). The edge index of $A$. tonsa (Table 1) would include this species into the omnivorous, group with certain tendency to carnivory (due to the proximity of the index to 900). Based on observations of faecal pellets of $A$. tonsa, Turner (1984b), classified this species as herbivorous. However, this method has been questioned since soft bodied organisms frequently cannot be recognized in faecal pellets and therefore the ingestion of microzooplankton is usually underestimated. Recently, Vargas \& González (2004) estimated that heterotrophic prey could contribute to $1 / 3$ of the total ingested carbon for A. tonsa and the other $2 / 3$ would be provided by autotrophic prey in the size range 5-23 $\mathrm{mm}$. One of the main differences of the mandible blade of this species is the presence of large dagger-like spinules on the outside of the gnatobase (Fig. 2A). These structures have usually been associated with carnivorous feeding modes, acting as brushes to clean the cutting edge (Ohtsuka \& Onbé 1991). This would explain the high Edge index of this species (896), which is close to the limit where it would be considered mainly as raptorial feeder.

Centropages brachiatus has usually been suggested to have an omnivorous feeding behavior, with highest clearance rates on flagellates and ciliates between 5 and $86 \mathrm{~mm}$ ESD (Turner \& Graneli 1992, Bonnet \& Carlotti 2001, Vargas \& González 2004). Mandible shape and edge index obtained in this study agrees with the observations made by Schnack (1982), who estimated an edge index of 740 for $C$. hamatus (Table 1).

According to its edge index, Oithona sp. is a typical carnivore, with a sharp toothed mandible. Both field and laboratory studies on feeding habits of the genus Oithona have demonstrated its capability to ingest a variety of prey items from bacterial aggregates (Kozheminkov 1979 fide Dirts \& Semenova 1984) to Acartia nauplii (Lampitt 1978), passing through diatoms (Turner 1986), particle laden mucus on larvacean houses (Alldredge 1972), faecal material detritus (González \& Smetacek 1994) and phytoflagelates (Dirts \& Semenova 1984). Therefore, this genus is considered primarily as omnivorous (Marshall \& Orr 1966,

TABLE 3

Mandible width as percentage of the carapace length of three calanoid copepod species

Diámetro mandibular como porcentaje de la longitud cefalororáxica de tres especies de copépodos calanoídeos

\begin{tabular}{|c|c|c|c|}
\hline Copepod species & $\begin{array}{l}\text { Mandible width as } \% \\
\text { of the carapace length }\end{array}$ & $\begin{array}{l}\text { Standard } \\
\text { deviation }\end{array}$ & $\begin{array}{l}\text { Number of } \\
\text { replicates }\end{array}$ \\
\hline Paracalanus parvus & 9.5 & 0.5 & 34 \\
\hline Centropages brachiatus & 7.9 & 0.3 & 34 \\
\hline Acartia tonsa & 6.2 & 0.3 & 29 \\
\hline
\end{tabular}


Lampitt 1978, Nakamura \& Turner 1997, Lonsdale et al. 2000). Studies made in Mejillones Bay suggest that Oithona sp. is capable of removing selectively small both autotrophs and heterotrophs nanoflagellates $<5 \mu \mathrm{m}$ (Vargas \& González 2004).

Herbivore species (such as $P$. parvus), present relatively large mandibles (in relation to CL), which could stem from the need to develop rigid and relatively larger mandibles in early developmental stages in order to manipulate large size prey, like diatoms. Omnivorous species (e.g., C. brachiatus), in turn, display an "intermediate" length of the mandible, since they must be adapted to a broad size spectrum of preys. A more carnivorous species, represented in this study by A. tonsa, has the smallest mandible width, which provides greater dexterity to handle mobile preys and should therefo- re be better adapted to ingest prey like flagellates and ciliates. It should be clarified that the Itoh edge index used here is a coarse way to estimate feeding modes and does not reflect well specific feeding behaviour. However, it is evident that the mandibles are structurally so different, even within the same feeding modes, that it is doubtful to think that they have the same functionality. In general, the Itoh index has the advantage of being a relatively simple tool to diagnose the different feeding modes of copepods. However due to the simplicity of this method, species with adaptations to feed on a wide spectrum of food particles (such as cyclopoid copepods in this study) can significantly differ from the Itoh index. For this reason, it is necessary to use additional information on the diet of the species to be able to correctly interpret the edge indices.

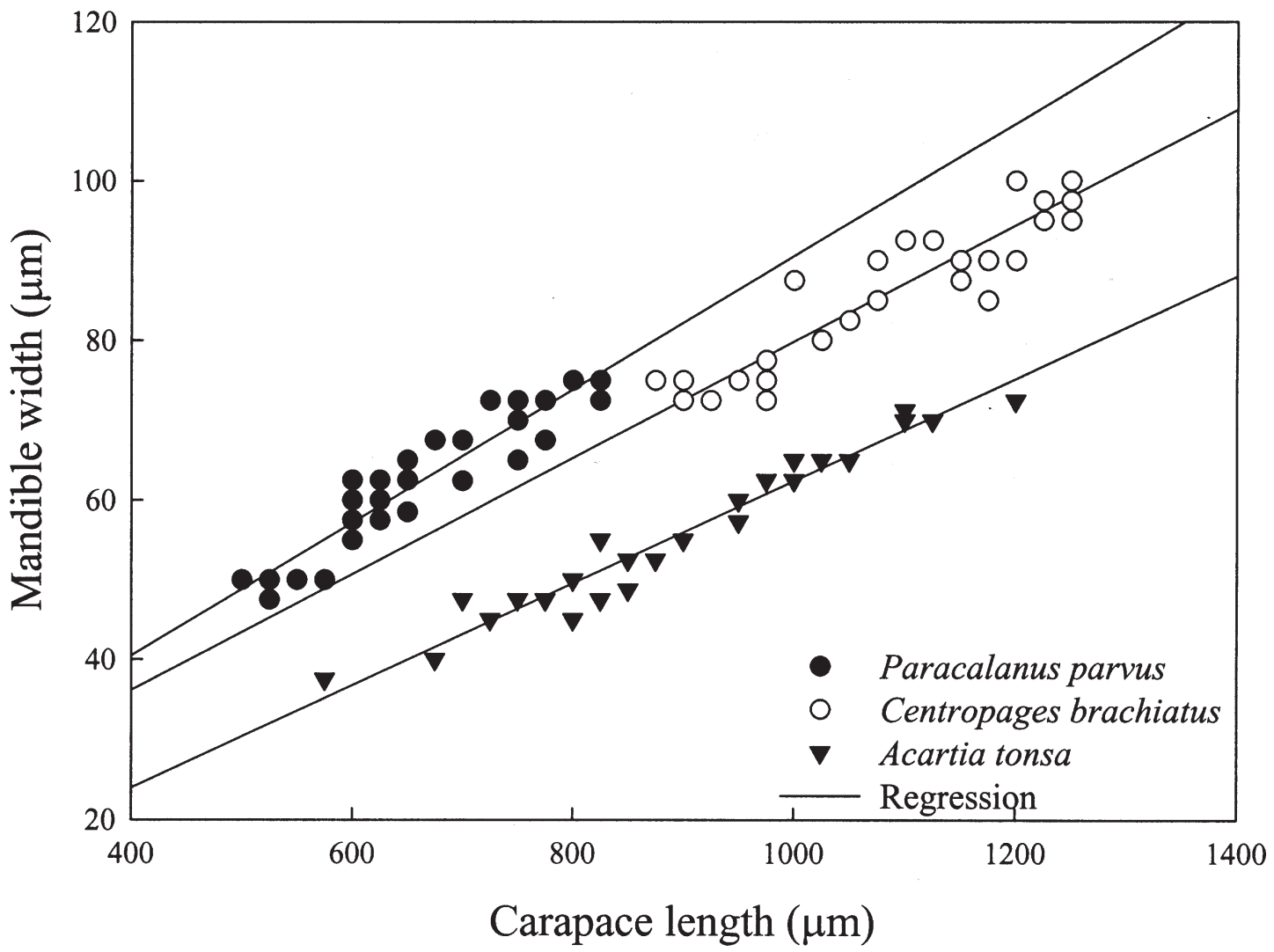

Fig. 3: Relationship between carapace length $(\mu \mathrm{m})$ and mandible width $(\mu \mathrm{m})$ of calanoid copepods Paracalanus parvus, Centropages brachiatus and Acartia tonsa.

Relación entre la longitud cefalotoráxica $(\mu \mathrm{m})$ y el diámetro mandibular $(\mu \mathrm{m})$ de las especies de copépodos calanoídeos Paracalanus parvus, Centropages brachiatus y Acartia tonsa. 


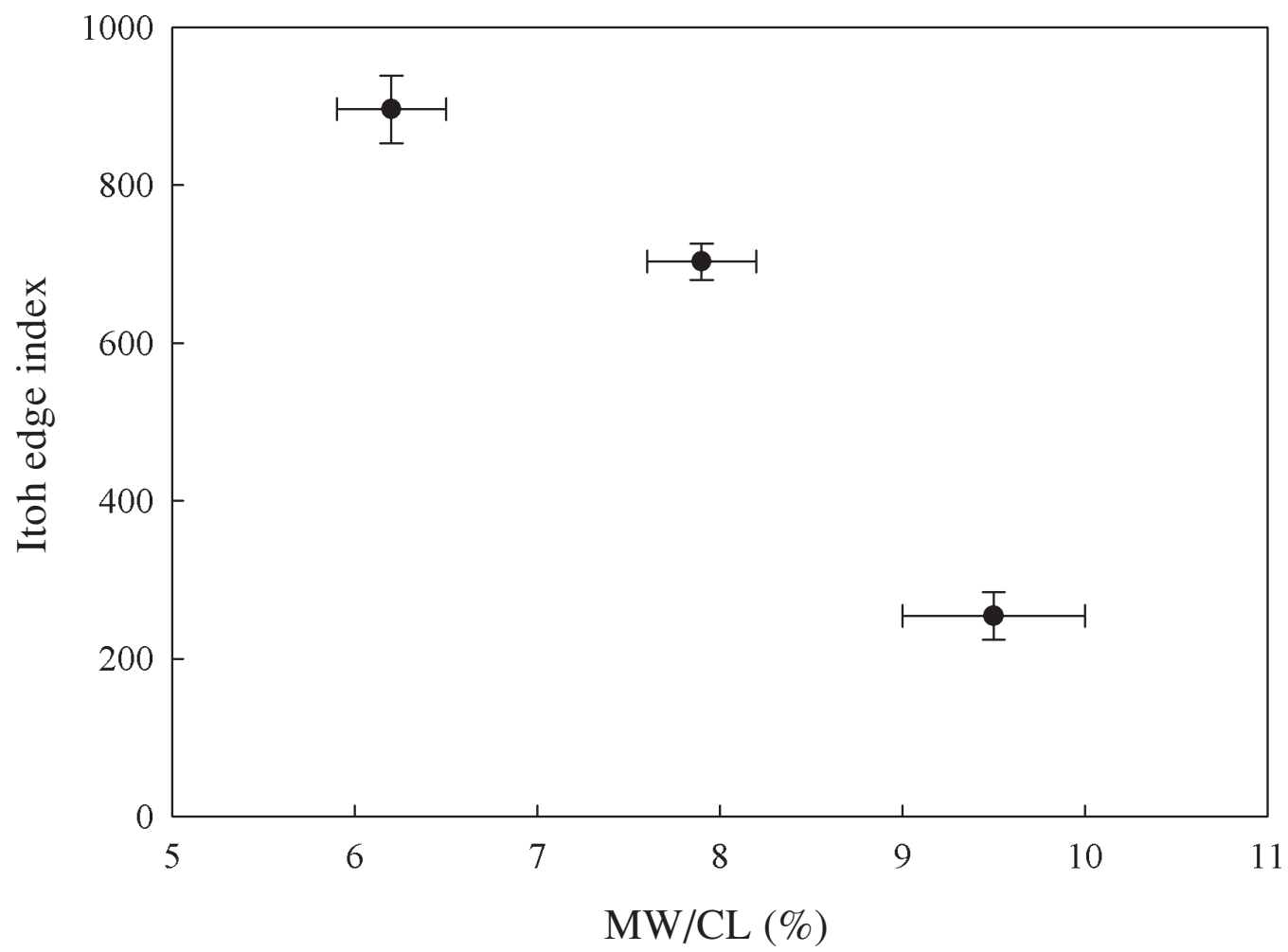

Fig. 4: Relationship between mandible width (as percentage of the carapace length) and Itoh edge index for three species of calanoid copepods. (A) Acartia tonsa; (B) Centropages brachiatus; (C) Paracalanus parvus. Vertical and horizontal bars denote $95 \%$ confidence interval.

Relación entre el diámetro mandibular (como porcentaje de la longitud cefalotoráxica) y el índice de Itoh para las tres especies de copépodos calanoídeos. (A) Acartia tonsa; (B) Centropages brachiatus; (C) Paracalanus parvus. Barras horizontales y verticales indican un intervalo de confianza de $95 \%$.

The significant relationship between the CL and the MW was observed only in calanoid species. For cyclopoid species, no significant relationships were observed, possibly due to the presence of more than one species of the same genus in the study area. Since these species were only identified to genus level, the presence of two morphologically close species could have caused bias in the analysis. The mandible-shape observations, together with the well described relation between $\mathrm{CL}$ and $\mathrm{MW}$ for the calanoid species, will provide an accurate method to estimate size-specific predation (in terms of prey type and size) by copepod predators. During normal upwelling conditions, the mandible morphology and the relationship between MW and CL are characteristics relatively constant for the dominant copepods of the study area (Giesecke \& González 2004). Thus, the analysis of mandibles in predator guts would allow the identification of the copepod prey species and their sizes, and further improve the knowledge of the feeding ecology of the mesozooplankton in the northern Humboldt Current of Chile.

\section{ACKNOWLEDGMENTS}

We would like to thank Cecilia Torres and Karla Locher for their help with copepod identification and drawings, respectively, and to the anonymous reviewers for comments. This research was supported by FONDECYT Project 1000419 to H. E. González. Additional support was provided by FONDAP- COPAS grant 150100007.

\section{LITERATURE CITED}

ALLDREDGE AL (1972) Abandoned larvacean houses: a unique food source in the pelagic environment. Science 177: 885-887. 
BONNET D \& F CARLOTTI (2001) Development and egg production in Centropages typicus (Copepoda: Calanoida) fed different food types: a laboratory study. Marine Ecology Progress Series 224: 133148.

BÅMSTEDT U, DJ GIFFORD，X IRIGOIEN，A ATKINSON \& M ROMAN (2000) Feeding. In: Harris RP, PH Wiebe, J Lenz, HR Skjoldal \& M Huntley (eds) ICES Zooplankton methodology manual: 297-400. Academic Press, London, United Kingdom.

CHECKLEY DM (1980) The egg production of a marine planktonic copepod in relation to its food supply: laboratory studies. Limnology and Oceanography 25: 430-446.

DIGBY PSB (1954) The biology of the marine planktonic copepods of Scoresby Sound, East Greenland. Journal of Animal Ecology 23: 298-338.

DIRTS AV \& TN SEMENOVA (1984) Experimental investigations of the feeding of Oithona similis Claus. Oceanography 24: 755-759.

ESCRIBANO R \& P HIDALGO (2000) Spatial distribution of copepods in the north of the Humboldt Current region off Chile during coastal upwelling. Journal of the Marine Biological Association of the United Kingdom 80: 283-290.

GIESECKE R \& HE GONZÁLEZ (2004) Feeding of Sagitta enflata and vertical distribution of chaetognaths related to low oxygen concentrations. Journal of Plankton Research 26: 475-486.

GONZÁLEZ HE \& V SMETACEK (1994) The possible role of the cyclopoid copepod Oithona in retarding vertical flux of zooplankton faecal material. Marine Ecology Progress Series 113: 233-246.

IRIARTE JL \& HE GONZÁLEZ (2004) Phytoplankton size structure during and after the 1997/98 El Niño in a coastal upwelling area of the northern Humboldt Current System Marine Ecology Progress Series 269: 83-90.

ITOH K (1970) A consideration on feeding habits of planktonic copepods in relation to the structure of their oral parts. Bulletin of Plankton Society of Japan 17: 1-10.

KIØRBOE T, E SAIZ \& M VIITASALO (1996) Prey switching behaviour in the planktonic copepod Acartia tonsa. Marine Ecology Progress Series 143: 65-67.

KARLSON K \& U BÅMSTEDT (1994) Planktivorous predation on copepods. Evaluation of mandible remains in predator guts as a quantitative estimate of predation. Marine Ecology Progress Series 108: 79-89.

LANDRY MR (1981) Switching between herbivory and carnivory by the planktonic marine copepod Calanus pacificus. Marine Biology 65: 77-82.

LANDRY MR, JM LEHNER-FOURNIER \& VL FAGERNESS (1985) Predatory feeding behavior of the marine cyclopoid copepod Corycaeus anglicus. Marine Biology 85: 163-169.

LAMPITT RS (1978) Carnivorous feeding by a small marine copepod. Limnology and Oceanography 23: 1228-12231.

LONSDALE DJ, DA CARON, MR DENNETT \& R SCHAFFNER (2000) Predation by Oithona spp. on protozooplankton in the Ross Sea, Antarctica. Deep-Sea Research 47: 3273-3283.

MARÍN VH \& GR OLIVARES (1999) Estacionalidad de la productividad primaria en Bahía Mejillones del sur (Chile): una aproximación proceso funcional. Revista Chilena de Historia Natural 72: 629-642.
MARSHALL SM \& AP ORR (1966) Respiration and feeding in some small copepods. Journal of the Marine Biological Association of the United Kingdom 46: 513-530.

NAKAMURA Y \& JT TURNER (1997) Predation and respiration by the small cyclopoid copepod Oithona similis: how important is feeding on ciliates and heterotrophic flagellates? Journal of Plankton Research 19: 1275-1288.

OHTSUKA S \& T ONBÉ (1989) Evidence of selective predation on larvaceans by the pelagic copepod Candacia bipinnata (Calanoidea: Candanciidae). Journal of Plankton Research 11: 869-872.

OHTSUKA S \& T ONBÉ (1991) Relationship between mouthpart structures and in situ feeding habits of species of the family Pontellidae (Copepoda: Calanoida). Marine Biology 111: 213-225.

OHTSUKA S, M SHIMOZU, A TANIMURA, M FUKUCHI, H HATTORI, H. SASAKI \& O MATSUDA (1996) Relationships between mouthpart structures and in situ feeding habits of five neritic calanoid copepods in the Chukchi and northern Bering Seas in October 1988. Polar Biology 9: 153-168.

ØRESLAND V (1991) Feeding of the carnivorous copepod Euchaeta antarctica in Antarctic waters. Marine Ecology Progress Series 78: 41-47.

PAFFENHÖFER G-A, JR STICKLER \& M ALCARAZ (1982) Suspension-feeding by herbivorous calanoid copepods: a cinematographic study. Marine Biology 67: 193-199.

RODRÍGUEZ L, V MARÍN, M FARÍAS \& E OYARCE (1991) Identification of an upwelling zone by remote sensing and in situ measurements, Mejillones Bay (Antofagasta, Chile). Ciencias Marinas (Chile) 55: 467-473.

SAITO H \& T KIØRBOE (2001) Feeding rates in the chaetognath $S$. elegans: effects of prey size prey swimming behavior and small-scale turbulence. Journal of Plankton Research 23: 1385-1398.

SCHNACK SB (1982) The structure of the mouth parts of copepods in Kiel Bay. Meeresforschungen 2: 89101.

SULLIVAN BK, CB MILLER, WT PETERSON \& AH SOELDNER (1975) A scanning Electron Microscope study of the mandibular morphology of boreal copepods. Marine Biology 30: 175-182.

TURNER JT (1984a) Zooplankton feeding ecology: contents of fecal pellets of the copepod Eucalanus pileatus and Paracalanus quasimodo from continental shelf waters of the Gulf of Mexico. Marine Ecology Progress Series 15: 27-46.

TURNER JT (1984b) Zooplankton feeding ecology: contents of fecal pellets of the Copepods Acartia tonsa and Labidocera aestiva from continental shelf waters near the mouth of Mississippi River. Marine Ecology 5: 265-282.

TURNER JT (1986) Zooplankton feeding ecology: contents of fecal pellets of the Cyclopoid Copepods Oncaea vetusta, Corycaeus amazonicus, Oithona plumifera, and $O$. simplex from the Northern Gulf of Mexico. Marine Ecology 7: 289-302.

TURNER JT \& GRANÉLI (1992) Zooplankton feeding ecology: grazing during enclosure studies of phytoplankton blooms from the west coast of Sweden.

Journal of Experimental Marine Biology and Ecology 157: 19-31.

TURNER JT, PA TESTER \& WJ CONLEY (1984) Zooplankton feeding ecology: predation by the 
marine cyclopoid copepod Corycaeus amazonicus upon natural prey. Journal of Experimental Marine Biology and Ecology 84: 191-202.

UNESCO (1968) Zooplankton sampling. Monographs on Oceanographic Methodology $\mathrm{N}^{\circ}$ 2, UNESCO Press, Paris, France. 174 pp.

Associate Editor: Sergio Navarrete

Received November 25, 2003; accepted August 17, 2004
VARGAS CA \& HE GONZALEZ (2004) Plankton community structure and carbon cycling in a Coastal Upwelling System I: Bacteria, microprotozoans and phytoplankton in the diet of copepods and appendicularians. Aquatic Microbial Ecology 34: 151-164. 